\title{
Knowledge, Attitude And Stigma of Dental Students Towards Hiv/Aids Patients
}

\author{
Faiza Amin ${ }^{1}$ \\ BDS, MDS \\ Kashif Aslam² \\ BDS, MSc \\ Sofia Ali Syed ${ }^{3}$ \\ BDS, M.Phil \\ Rizwan Nadim ${ }^{4}$ \\ BDS, MPH
}

BACKGROUND: In most areas of the world there is a decrease of the HIV/ AIDS epidemic that can be observed from international literature. Data from the Asian region recommends increasing incidences. Understanding knowledge levels and attitudes and relate them toward willingness to treat and stigma regarding HIV/AIDS is a significant constituent to project acceptable and culturally appropriate awareness and prevention programs.

OBJECTIVES: To evaluate level of knowledge, attitudes, willingness to treat and stigma associated with HIV/AIDS of dental students and house officers of Dow Dental College.

METHODOLOGY: A cross-sectional questionnaire survey was conducted among a total of 196 dental students of 1 , 2, 3, 4 professional years and house officers of 2015-2016 academic session. By using a self-administered, structured questionnaire to examine their knowledge, attitudes and behavior towards HIV/AIDS was the approach. The descriptive indices such as percentages were used to express the knowledge level among the students. Independent $\mathrm{t}$ test was used to evaluate the attitude and stigma of these students towards HIV/AIDS with SPSS 17.0.

RESULTS: A total of 196 questionnaires were completed and returned, with response rate of $96.5 \%$. Overall, the knowledge of the students was adequate except first year and second year students. The attitude of the students toward people living with HIV/AIDS was positive. House officers discriminate and stigmatize most among all the students. CONCLUSION: Despite their adequate level of knowledge majority of students have negative attitude and willingness towards treatment of patients with HIV/AIDS.

KEY WORDS: HIV/AIDS, Knowledge and attitude of dental students.

HOW TO CITE: Amin F, Aslam K, Syed SA, Nadim R. Knowledge, attitude and stigma of dental students towards hiv/aids patients. J Pak Dent Assoc 2018;27(3):140-46.

DOI: https://doi.org/10.25301/JPDA.273.140

Received: 28 February 2018, Accepted: 29 March 2018

\section{INTRODUCTION}

I $\mathrm{n}$ this contemporary era, Human Immunodeficiency (HIV) and the Acquired Immune Deficiency Syndrome (AIDS) is a most significant public health challenge. ${ }^{1}$ It becomes a major health issue worldwide after recognition in 1981. By the end of 2014, approximately 1.2 million people had died from AIDS-related infections and 34.3-41.4 million people were living with HIV infection. ${ }^{2}$ In Pakistan, first case of HIV was diagnosed in 1986 and was reported in $1987 .{ }^{3}$ According to the national estimates, in Pakistan

1. Associate Professor/Vice Principal, Department of Dental Materials, Dow Dental College, Dow University of Health Sciences, Karachi.

2. Associate Professor, Department Of Prosthodontics, Dow Dental College, Dow University Of Health Sciences, Karachi

3. Associate Professor, Department of Oral Pathology, Dow Dental College, Dow University of Health Sciences, Karachi.

4. Ph.D Scholar, University of Wolverhampton, U.K.

Corresponding author: "Dr. Faiza Amin" < faiza.ameen@duhs.edu.pk > there are 102,000 people infected with HIV. ${ }^{4}$ In Pakistan it is now classified into concentrated phase of the epidemic because of its high prevalence. ${ }^{5}$ The mode of transmission is mainly because of heterosexuals $(52.55 \%)$ which is followed by (11.73\%) blood transfusion. ${ }^{6}$ In Asia region Pakistan is among 12 countries which account for more than $90 \%$ of the infected people living with HIV. ${ }^{7}$ Globally, during last decade new HIV infections have dropped by $0.7 \%$. But in Pakistan the disease burden and incidence of HIV is rising at disturbing pace. In Pakistan there is a $17.6 \%$ increase in annual incidence of HIV compared to $2.2 \%$ for the rest of the world according to Global disease burden (GBD). ${ }^{8}$ The condition is becoming more poorer as there is very low coverage $(5.87 \%)$ of antiretroviral treatment (ART) in Pakistani patients. ${ }^{9}$

Fear of HIV infection creates major health concerns among health care personnel. This produces a barrier to 
effective educational efforts about AIDS and related awareness. The consequences of this fear might lead to unwillingness to treat AIDS infected patients. ${ }^{10}$ It has been observed that health care staff are lacking in appropriately managing and counseling HIV and AIDS patients. A huge knowledge gap has been notified among health care personnel regarding diagnosis and treatment of HIV and AIDS. ${ }^{11}$

In a study conducted by Crossley Mat al ${ }^{12}$ the author found that there were lacking in the knowledge regarding transmission routes of HIV and AIDS but found good knowledge about oral manifestations associated with HIV and AIDS. Lack of knowledge was found among Tanzanian health care workers regarding treatment procedures related to HIV and AIDS. This was result in unwillingness to provide care for HIV patients. ${ }^{13}$ In Pakistan a study conducted by Shaikh FD et al concluded in their study there is a need for further education regarding knowledge, symptoms and modes of transmission of HIV and AIDS. ${ }^{11}$ Similar findings have been reported among nurses, dentists and health care personnel in Kenya, Brazil, Singapore, South Africa and Iran. ${ }^{14-16}$ Due to the alarmingly increasing spread of HIV in the Pakistan, the present study aimed to address the suspected deficiency in the level of understanding and awareness of this disease among clinical and nonclinical dental students at the Dow University of Health Sciences. The study was planned to assess the students' knowledge of HIV/AIDS and its transmission and attitudes about related issues such as ethical obligations, infection control regulations, willingness to treat HIV-positive patients, fear of contracting HIV occupationally, and feelings about HIV-positive patients.

\section{METHODOLOGY}

This cross-sectional survey was conducted from August to December 2015 at Dow Dental College, Dow University of Health Sciences Karachi on all dental students who were enrolled in Dow Dental College, Dow University of Health Sciences Karachi in the academic year 2015-2016.The survey instrument was a self-administered anonymous questionnaire in the English language. The study included a convenience sample comprising dental students of all basic and clinical year (1, 2 3, 4 professional years and house officers) Permission for study was also taken from Dean of Dentistry of Dental Faculty of Dow University of Health Sciences. The purpose of the study was explained clearly and, a written consent was obtained from the students. All the questions were anonymous, participant's voluntary took part in the study, and consent was taken from them and no incentive was given for completing the survey. The questionnaire was made up of three parts.

1. Part I focused on the socio-demographic characteristics of the respondents, including age gender and education level. 2. Part II includes close-ended questions related to knowledge and awareness of HIV/AIDS.

3. Part III contained questions about the attitude towards the willingness to treat HIV/AIDS patients, stigma and discrimination against HIV/AIDS patients.

The answer to each question about attitude was rated on a five point Likert scale (strongly agree, agree, neutral, disagree, and strongly disagree).

SPSS software version 17.0 was used for statistical analysis. Frequency and percentages were used to describe gender, level of education. The descriptive indices such as percentages were used to express the knowledge level among the students. Independents t test was used to assess attitude and stigma of the students and house officers regarding HIV/AIDS

\section{RESULTS}

Out of 200 students who were sent the survey, a total of one ninety three completed the survey. Therefore the respond rate was $96.5 \%$. These participants were from first, second, third, final professional year and house officers (Figure 1)

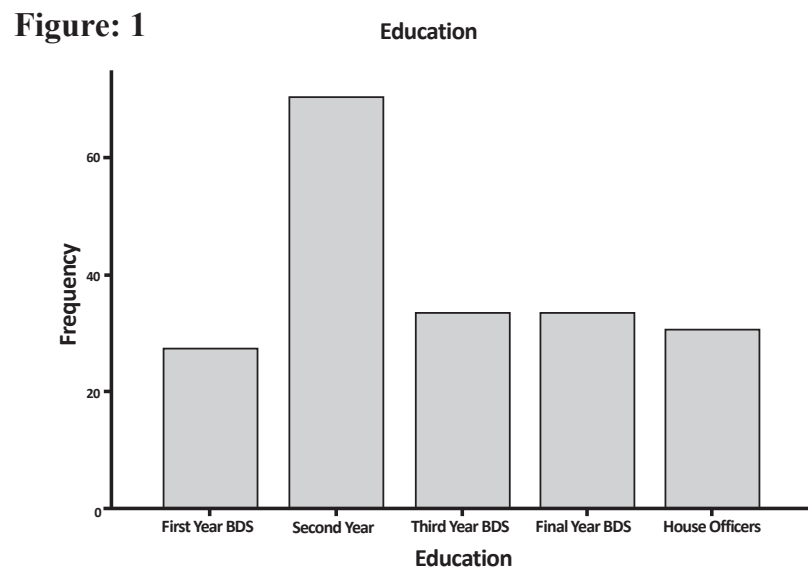

\section{Knowledge of Dental Students regarding HIV/AIDS: Table 1}

On question 1 (HIV is same as AIDS), majority of students have inadequate knowledge and were not aware of the fact that HIV is same as AIDS.

Regarding question 2 (saliva act as a vehicle of transmission), students from all the professional years and house officers have enough knowledge that saliva can act as vehicle of transmission.

For question 3 (needle stick injury can transmit AIDS/HIV), all the students and House officers have remarkable knowledge.

Regarding question 4 (Aerosol from hand piece can cause HIV) in adequate knowledge were found among first 
Table 1: Knowledge among Dental Students Regarding HIV/AIDS

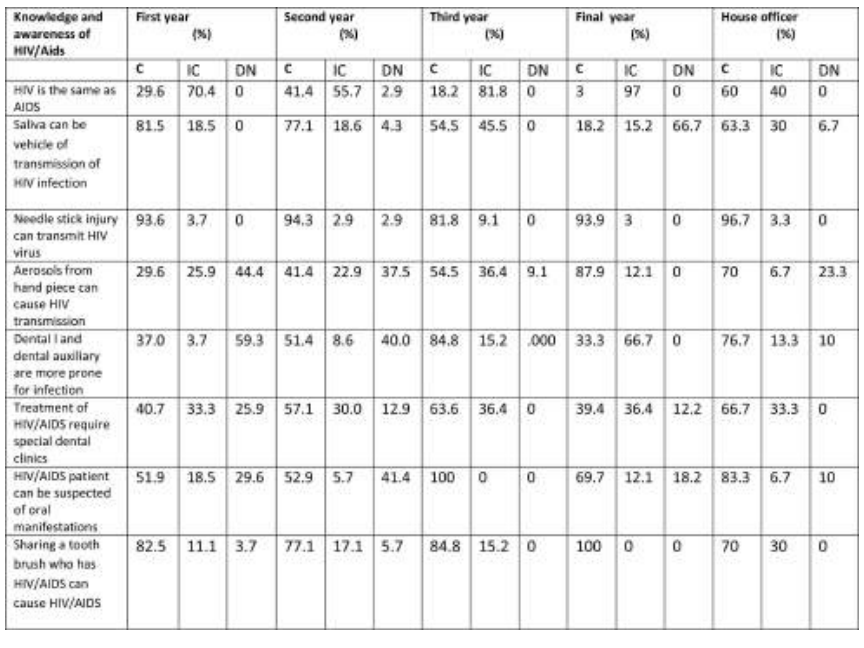

$\mathrm{C}=$ Correct,

$\mathrm{IC}=$ Incorrect,

$\mathrm{DN}=$ Don't Know

students but second, third, final year students and house officers present sufficient knowledge.

For question 5 (Dental and dental auxiliary are more prone) Inadequate knowledge were found among first year and second year students.

Regarding question 6 (Treatment of HIV/AIDS require special dental clinics) insignificant knowledge were obtained from first year and second year students.

On question 7 (HIV/AIDS patient can be suspected of oral manifestations) inadequate knowledge was observed among first year and second year students.

For question 8 (Sharing a tooth brush who has HIV/AIDS can cause HIV/AIDS) all the students have the adequate knowledge that AIDS/HIV can be transmitted if a person used toothbrush of AIDS/HIV patients.

\section{Attitude of Dental students to treat HIV/AIDS patients: Table 2}

On question 1 (One can safely treat HIV patients) when first year students compared with second year, third year and final year students highly insignificant results were found among all the students. (Independent $t$ test were used to assess attitude of the students).

On question 2 (It is my moral responsibility to treat HIV/AIDS patient) significant differences were found among the attitude of the students of the first year when compared with the students of third year. Second year students when compared with third year, final year and house officers, it was found that statistically significant differences were found in attitude of third year students. All these students have negative attitude towards realization that this is their moral responsibility as health care staff to treat HIV patients.

On question 3 (Patients with HIV can lead normal life)
Table 2: Attitude of Dental Students to Treat HIV/AIDS Patients

\begin{tabular}{|c|c|c|c|c|c|c|c|c|c|}
\hline \multicolumn{2}{|c|}{ STUDENTS } & \multicolumn{2}{|c|}{$\begin{array}{l}\text { One can safely } \\
\text { treat HIV patients }\end{array}$} & \multicolumn{2}{|c|}{$\begin{array}{l}\text { It is my moral } \\
\text { responsibility to } \\
\text { treat HIV/AIDS } \\
\text { patient }\end{array}$} & \multicolumn{2}{|c|}{$\begin{array}{l}\text { Patients with HIN } \\
\text { can lead normal } \\
\text { life }\end{array}$} & \multicolumn{2}{|c|}{$\begin{array}{l}\text { I will treat HIV } \\
\text { patients for my } \\
\text { electives }\end{array}$} \\
\hline & & Mean[SD) & $\begin{array}{l}p \\
\text { Yalue }\end{array}$ & $\operatorname{Mean}(\mathrm{SO})$ & \begin{tabular}{|l|} 
Palue \\
value
\end{tabular} & Mean(SO) & $\begin{array}{l}\text { p patue } \\
\text { val }\end{array}$ & Mean(SD) & PVALUE \\
\hline $1^{n}$ year(mean.sd) & $\begin{array}{l}\text { 2nd } \\
\text { year(mean.sd) } \\
3^{\text {red }} \\
4^{\text {th }} \\
\text { HO }\end{array}$ & \begin{tabular}{|l|}
$2.52(1.087)$ \\
\\
$2.43(1.187)$ \\
$1.88(1.686)$ \\
$2.52(1.087$ \\
$2.00(1.017)$
\end{tabular} & $\begin{array}{l}.031 \\
.055 \\
.031 \\
.068\end{array}$ & $\begin{array}{l}1.48(.753) \\
2.43(1.187) \\
1.88(1.386) \\
1.91(1.042 \\
1.73(.868)\end{array}$ & $\begin{array}{l}390 \\
.012 \\
.32 \\
.961\end{array}$ & \begin{tabular}{|l|}
$2.59(.931)$ \\
\\
$2.74(1.32)$ \\
$2.59(.931)$ \\
$2.73(.977)$ \\
$2.77(1.223)$
\end{tabular} & $\begin{array}{l}.004 \\
.254 \\
.589 \\
.032\end{array}$ & $\begin{array}{l}2.63(1.182) \\
\\
2.71(1.276) \\
2.06(1.321) \\
3.21(1.386) \\
2.87(1.137)\end{array}$ & $\begin{array}{l}0.766 \\
0.087 \\
0.089 \\
0.444\end{array}$ \\
\hline $2^{\text {min }}$ year $[$ mean.sd) & $\begin{array}{l}3^{\text {rid }} \\
\text { 4th } \\
\text { HO }\end{array}$ & $\begin{array}{l}2.43(1.187) \\
1.88(1.386) \\
1.91(1.042) \\
2.00(1.017)\end{array}$ & $\begin{array}{l}.040 \\
.034 \\
.088\end{array}$ & $\begin{array}{l}1.77(.966) \\
1.09(3.84) \\
1.52(.566) \\
1.73(.868)\end{array}$ & $\begin{array}{l}.000 \\
971 \\
.383\end{array}$ & $\begin{array}{l}2.74(1.326) \\
3.24(1.458) \\
2.73(.977) \\
2.77(1.223)\end{array}$ & $\begin{array}{l}0.087 \\
0.952 \\
0.933\end{array}$ & $\begin{array}{l}2.71(1.276) \\
2.06(1.321) \\
3.21(1.386) \\
2.87(1.137)\end{array}$ & $\begin{array}{l}0.018 \\
0.075 \\
0.573\end{array}$ \\
\hline $3^{n}$ year(mean.sd) & $\begin{array}{l}\text { 4th } \\
\text { HO }\end{array}$ & $\begin{array}{l}1.88(1.386) \\
1.91(1.042) \\
2.00(1.017\end{array}$ & $\begin{array}{l}.920 \\
.696\end{array}$ & $\begin{array}{l}1.09(.384) \\
1.52(.566) \\
1.73(.868)\end{array}$ & $\begin{array}{l}389 \\
025\end{array}$ & $\begin{array}{l}3.24(1.458) \\
2.73(.977) \\
2.77(1.223)\end{array}$ & $\begin{array}{l}.097 \\
0.168\end{array}$ & $\begin{array}{l}2.06(1.321) \\
3.21(1.386) \\
2.87(1.137)\end{array}$ & $\begin{array}{l}0.001 \\
0.012\end{array}$ \\
\hline $4^{\text {th }}$ year (mean.sd) & Hо & $\begin{array}{l}1.91(1.042) \\
2.00(1.017\end{array}$ & .728 & $\begin{array}{l}1.52(.566) \\
1.73(.868)\end{array}$ & 325 & $\begin{array}{l}2.73(0.977) \\
2.77(1.223)\end{array}$ & 0.888 & $\begin{array}{l}3.21(1.386) \\
2.87(1.137)\end{array}$ & .287 \\
\hline
\end{tabular}

among all the students only second year students and house officers have the attitude that the patient with AIDS/HIV cannot lead to normal life.

On question 4 (I will treat HIV patients for my electives) significant results were found regarding the question among students of second year when compared with third year students and third year students when compared to final year and house officers.

\section{Stigma and Discrimination of Dental Students against HIV/AIDS patients: Table 3}

On question 1 (If my colleague or assistant is HIV infected I will stop working with him or her) when stigma

Table 3: Stigma and Discrimination of Dental Students against HIV/AIDS

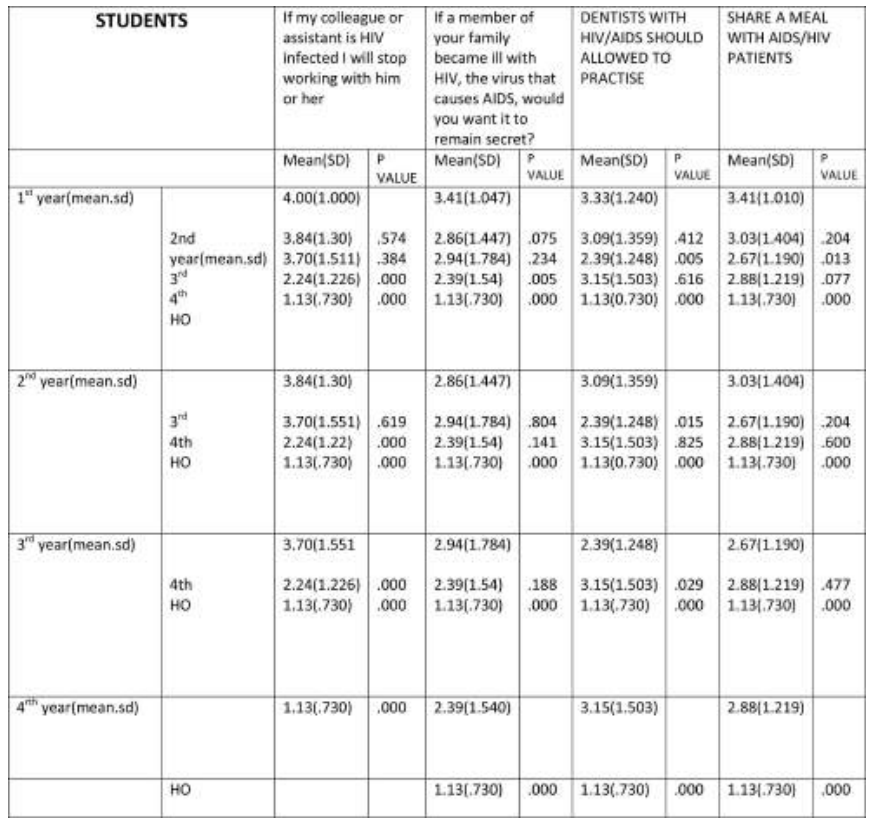


regarding the question is compared between first year students with the rest of professional years it was found that significant difference was observed in fourth year students and house officers When second year students were compared with other students and house officers significant differences were observed in the stigmatization of final year and house officers.

On question 2 (If a member of your family became ill with HIV, the virus that causes AIDS, would you want it to remain secret?) Highly insignificant results were obtained in this regard as only house officers among all the students were maintained the secrecy.

On question 3 (Dentists with HIV/AIDS should allowed to practice). According to house officers only in comparison with all other students that dentists should allowed to practice if he/she is suffered from AIDS/HIV.

On question 4 (Share a meal with AIDS/HIV patients) highly insignificant results were obtained in this regard as only house officers among all the students were responded that they can share meal with AIDS/HIV patients.

\section{DISCUSSION}

This study investigated dental students' knowledge of AIDS/HIV and attitude towards infected patients and stigma to treat these infected patients. Dental and Medical workers are at high occupational risk during their professional training period for developing these infections. In this regard a survey has been conducted on dental students about different parts of knowledge and awareness of HIV/AIDS.

In our survey, excellent knowledge was observed about HIV/AIDS patients, but unfortunately this knowledge was not meaningfully related with the willingness to treat HIV/AIDS patients. In a study conducted on 174 dental students from Japan, the majority of respondents have more than average knowledge about HIV/AIDS. Regarding attitude to treat HIV-positive and negative patients $22 \%$ percent reported that they would have the same attitude toward treating both. ${ }^{17}$ Where as in this study it was found that there were no difference in the attitude of the students to treat HIV/AIDS patients from first year to final year.

During dental operation procedures it is possible to transmit HIV/AIDS. ${ }^{16}$ HIV/AIDS can be transmitted through saliva or blood contaminated instruments and equipments. It can also be transmitted by inhalation of aerosol emitted from hand pieces. ${ }^{18}$ However, in previous studies very few students have the knowledge HIV/AIDS can transmit through inhalation of aerosol emitted from hand pieces. The results were similar with our study as majority of first year students don't know that HIV/AIDS can be transmitted through aerosol inhalation. But their results were in contrast with results of our study as second, third final year students and house officers have the enough knowledge in this context. ${ }^{18,19}$ In one previous study, it was found that more than half of the students participants believed that there is no such route of transmission exist. ${ }^{20}$ There is statistically significant difference in the knowledge of the participants when asked that aerosols from hand piece can cause HIV transmission among first, second and final year students. Statistically significant results were observed in the present study regarding concerns that aerosols from hand piece can cause HIV transmission. According to $\mathrm{CDC}$ guidelines ${ }^{21}$ dental health care personnel should position patients properly and make appropriate use of barriers e.g., surgical masks, face shields, high-volume evacuators, rubber dams and gowns. This will prevent the dentists and assistant from contact with splashes and spatter. As theses splashes and spatter creates a visible spray that is released from rotary surgical instruments and dental equipments e.g air-water syringes, handpieces and ultrasonic scalers. This spray contains mainly a large-particle spatter of blood, microorganisms, aerosol, water, debris and saliva.

Saliva can be a vehicle for the transmission of AIDS/HIV. In a study conducted by Askarian $\mathrm{M}$ at al, some students $(24.5 \%)$ agreed that saliva can be a vehicle for the transmission. However, majority of students $72.5 \%$ declared it is possible that a CPR given to HIV/AIDS patients will might transmit the infection. ${ }^{14}$ In our study, first, second, final year students and house officers did have the sound knowledge in this context.

Mostafa Sadeghi et a ${ }^{22}$ found in their study that most of the students were aware of the major oral manifestations of AIDS: Kaposi's sarcoma, major aphthous and oral candidiasis, which was also found in the current study.

Similar results were observed in a study conducted in Peshwar (Pakistan) by $\mathrm{H}$ Khan at $\mathrm{el}^{23}$ who concluded that there is a satisfactory awareness among the medical students entering into the profession. An acceptable difference was recorded among clinical, preclinical and 2 (non-clinical students) regarding their knowledge and attitude about HIV and AIDS.

Key factor in transmitting these contagious infections are contaminated needles. In our part of the world one of the significant modes of transmitting hepatitis $\mathrm{B}$ and $\mathrm{C}$ virus is through these needles pricks. ${ }^{24,25}$ The current study analyzed that majority of the students among all the professional years (1st, 2nd, 3rd and 4rth) and house officers knew about needle safety. It is mandatory that students should be given the training that both patient safety and personal safety should be the priority. ${ }^{26,27}$

The results of this study found that dental students at Dow Dental College have positive attitudes towards treating HIV/AIDS patients. In this study, the general willingness to treat HIV positive patients when first year compared with 
second year, third year and final year authors found that no significant difference in attitude was found among all students in comparison with the results from the study of $\mathrm{Hu}$ et al. ${ }^{28}$ However, our results regarding the attitude towards treating HIV/AIDS patients were not positive in comparison with the study conducted by Kuthy et $\mathrm{al}^{29}$ and Seacat and Inglehart. ${ }^{30}$

In the current study, there was a considerable negative attitude of the students towards AIDS and HIV positive patients. Almost about more than half of the students did not want to treat patients having HIV/AIDS as their electives. The same results were found by Brook. ${ }^{11}$ In the study conducted in Grecian schools by Merakou et al found that only a small percentage of the students $(5 \%)$ stated that they would reject their friends infected with HIV/AIDS. ${ }^{21}$ Approximately half of students in our study expressed that an infected student should not be allowed to enter an ordinary school. Similarly results were reported in study conducted by Agrawal et al in India. ${ }^{13}$ These are serious issues regarding attitude towards AIDS/HIV because of lack of awareness and education and they need to be addressed. Similar results were seen in a study conducted by FD Shaikh at $\mathrm{el}^{11}$ in which researchers feel that it is essential to change the attitudes of medical students towards AIDS/HIV patients. There seems to be a high rate of anxiety and bias toward HIV-infected persons and the disease.

Statistically significant association should be observed regarding attitude towards their responsibility to treat patients having HIV/AIDS. Prashant B Patil et $\mathrm{al}^{31}$ in their study by using a five-point Likert scale found that students showed overall negative attitude towards HIV/AIDS patients. Similar results were found in the current study that students have negative attitude to treat HIV/AIDS patients. The finding differs from previous researchers, who found students having positive attitude about HIV/AIDS..$^{22,32-34}$

Stigma is frequently related with human rights and discrimination. According to Erving Goffman ${ }^{35}$ stigma is an undesirable or discrediting attribute that an individual possesses, thus reducing that individual's status in the eyes of society. In our study when asked the participants that would they stop working with colleague if he/she had HIV/AIDS, majority of them replied affirmative to it. Parker and Aggleton et al, convincingly argue that stigma and stigmatization are central to establishing the prevailing social order as they function at the connection between power, culture, and difference. ${ }^{36}$

The current study has numerous limitations. First, in our religious culture, the investigators are limited in asking questions concerning students' sexual beliefs and behaviors. Second, the honesty of students' responses may be questioned due to self-report nature of the questionnaire. Third, the results of the study may not be applicable to adolescents who are not attending dental school. They only generalized to similar populations of students.

\section{CONCLUSION}

Under the limitations of the study following conclusion was drawn: There was insufficient knowledge among first and second year students. Among third, final year students and house officer's majority of them have sufficient knowledge regarding HIV/AIDS infection but majority of them were not willing to treat HBV/AIDS patients. Dental students appear to have a more negative attitude towards treating HIV/AIDS patients. Refusal to treat patients with HIV was primarily associated with lack of ethical responsibility and fears related to cross-infection.

\section{ACKNOWLEDGEMENT}

The authors are grateful to Dr. Taqi Assistant Professor department of community Dentistry Dow Dental College, Dow University of Health Sciences for his assistance in statistical Analysis.

\section{CONFLICT OF INTEREST}

None declared.

\section{REFERENCES}

1. Turhan O, Senol Y, Baykul T, Saba R, Yalçin A. Knowledge, attitudes and behaviour of students from a medicine faculty, dentistry faculty, and medical technology Vocational Training School toward HIV/AIDS. Int J Occup Med Environ Health. 2010;23(2):153-60.

https://doi.org/10.2478/v10001-010-0008-5

2. Gowing LR, Ali RL, Allsop S, Marsden J, Turf EE, West R, et al. Global statistics on addictive behaviours: 2014 status report. Addiction. 2015;110(6):904-19.

https://doi.org/10.1111/add.12899

3. Keesstra SD, Quinton JN, van der Putten WH, Bardgett RD, Fresco LO.The significance of soils and soil science towards realization of the United Nations Sustainable Development Goals. Soil. 2016;2(2):111. https://doi.org/10.5194/soil-2-111-2016

4. Wolf RC, Adams D, Dayton R, Verster A, Wong J, Romero M, et al. Putting the $t$ in tools: a roadmap for implementation of new global and regional transgender guidance. J. Int. AIDS Soc.2016;19(3Suppl 2).

5. Bokhari A, Nizamani NM, Jackson DJ, Rehan NE, Rahman M, Muzaffar R, et al. HIV risk in Karachi and Lahore, Pakistan: an emerging epidemic in injecting and commercial sex networks. Int $\mathrm{J}$ STD AIDS 2007;18(7):486-92. 
https://doi.org/10.1258/095646207781147201

6. Bhurgri Y. HIV/AIDS in Pakistan. JPMA. 2006;56(1):1-2.

7. HIV/AIDS JUNPo. HIV in Asia and the Pacific. Geneva: UNAIDS. 2013.

8. Vos T, Barber RM, Bell B, Bertozzi-Villa A, Biryukov S, Bolliger I, et al. Global, regional, and national incidence, prevalence, and years lived with disability for 301 acute and chronic diseases and injuries in 188 countries, 1990-2013: a systematic analysis for the Global Burden of Disease Study 2013. The Lancet. 2015;386(9995):743-800. https://doi.org/10.1016/S0140-6736(15)60692-4

9. Waheed U, Satti HS, Arshad M, Farooq A, Rauf A, Zaheer HA. Epidemiology of HIV/AIDS and Syphilis among High Risk Groups in Pakistan. Pak J Zool. 2017;49(5):1829-34.

https://doi.org/10.17582/journal.pjz/2017.49.5.1829.1834

10. Kopacz DR, Grossman LS, Klamen DL. Medical students and AIDS: knowledge, attitudes and implications for education. Health Educ Res. 1999;14(1):1-6.

https://doi.org/10.1093/her/14.1.1

11. Shaikh FD, Khan SA, Ross MW, Grimes RM. Knowledge and attitudes of Pakistani medical students towards HIV-positive and/or AIDS patients. Psychol Health Med . 2007;12(1):7-17.

https://doi.org/10.1080/13548500500477667

12. Crossley M. An investigation of dentists' knowledge, attitudes and practices towards HIV+ and patients with other blood-borne viruses in South Cheshire, UK. Br Dent J. 2004;196(12):749-54. https://doi.org/10.1038/sj.bdj.4811382

13. Marchal B, Brouwere VD, Kegels G. HIV/AIDS and the health workforce crisis: what are the next steps? Trop Med Int Health. 2005;10(4):300-4.

https://doi.org/10.1111/j.1365-3156.2005.01397.x

14. Askarian M, Mirzaei K, Assadian O. Iranians' attitudes about possible human immunodeficiency virus transmission in dental settings. Infect Control Hosp Epidemiol. 2007;28(2):234-7.

https://doi.org/10.1086/509860

15. Gachigo J, Naidoo S. HIV/AIDS: the knowledge, attitudes and behaviour of dentists in Nairobi, Kenya. SADJ: 2001;56(12):587-91.

16. Oliveira E, Narendran S, Falcao A. Brazilian dental students' knowledge and attitudes towards HIV infection. J Int Assoc Provid AIDS Care. 2002;14(4):569-76.

17. Kitaura H, Adachi N, Kobayashi K, Yamada T. Knowledge and attitudes of Japanese dental health care workers towards HIV-related disease. Int J Dent Oral Health. 1997;25(3-4):279-83.

https://doi.org/10.1016/S0300-5712(96)00030-9

18. Khanghahi BM, Jamali Z, Azar FP, Behzad MN, Azami-Aghdash S. Knowledge, attitude, practice, and status of infection control among Iranian dentists and dental students: a systematic review. J Dent Res
Dent Clin Dent Prospects. 2013;7(2):55.

19. Blignaut $\mathrm{E}$. The role of the dental profession in the AIDS epidemic. Practitioners corner. J Dent Assoc S Afr. 1994;49:113-52.

20. Erasmus S, Luiters S, Brijlal P. Oral Hygiene and dental student's knowledge, attitude and behaviour in managing HIV/AIDS patients. Int J Dent Hyg. 2005;3(4):213-7.

https://doi.org/10.1111/j.1601-5037.2005.00137.x

21. Kohn WG, Collins AS, Cleveland JL, Harte JA, Eklund KJ, Malvitz DM. Guidelines for infection control in dental health-care settings2003. US Government Printing Office; 2003.

22. Sadeghi M, Hakimi H. Iranian dental students' knowledge of and attitudes towards HIV/AIDS patients. J Dent Educ. 2009;73(6):740-5.

23. Khan H, Ishaq M, Ishaq T. Knowledge and attitude of students regarding HIV/AIDS in Peshawar University. JPMA. 2008;33(1):9.

24. Khan AJ, Luby SP, Fikree F, Karim A, Obaid S, Dellawala S, et al. Unsafe injections and the transmission of hepatitis $\mathrm{B}$ and $\mathrm{C}$ in a periurban community in Pakistan. Bulletin of the World Health Organization. 2000;78(8):956-63.

25. Luby S, Qamruddin K, Shah A, Omair A, Pahsa O, Khan A, et al. The relationship between therapeutic injections and high prevalence of hepatitis $\mathrm{C}$ infection in Hafizabad, Pakistan. ?Epidemiol. Infect 1997;119(03):349-56.

https://doi.org/10.1017/S0950268897007899

26. Shen C, Jagger J, Pearson RD. Risk of needle stick and sharp object injuries among medical students. Am J Infect Control. 1999;27(5):435-7.

https://doi.org/10.1016/S0196-6553(99)70010-6

27. Norsayani MY, Noor Hassim I. Study on incidence of needle stick injury and factors associated with this problem among medical students. J Occup Health . 2003;45(3):172-8.

https://doi.org/10.1539/joh.45.172

28. Hu S-W, Lai H-R, Liao P-H. Comparing dental students' knowledge of and attitudes toward hepatitis B virus-, hepatitis C virus-, and HIVinfected patients in Taiwan. AIDS Patient Care \& STDs. 2004;18(10):587-93.

https://doi.org/10.1089/apc.2004.18.587

29. Kuthy RA, McQuistan MR, Riniker KJ, Heller KE, Qian F. Students' comfort level in treating vulnerable populations and future willingness to treat: results prior to extramural participation. J Dent Educ 2005;69(12):1307-14.

30. Seacat JP, Inglehart MR. Education about treating patients with HIV infections/AIDS: the student perspective. J Dent Educ 2003;67(6):630-40.

31. Patil PB, Sreenivasan V, Goel A. Knowledge of HIV/AIDS and attitude of dental students towards HIV/AIDS patients: A crosssectional survey. J Educ Ethics Dent. 2011;1(2):59. 
32. Sheikh H, Shankar S, Vinay S. Knowledge and attitudes of undergraduate dental students in the oxford dental college hospital and research centre, Bangalore toward patients with HIV/AIDS. JIADS. 2011;2(1):1-5.

33. Ryalat ST, Sawair FA, Shayyab MH, Amin WM. The knowledge and attitude about HIV/AIDS among Jordanian dental students:(Clinical versus pre clinical students) BMC. 2011;4(1):191.

https://doi.org/10.1186/1756-0500-4-191

34. Shan V, Shethwala ND, Bala D. Knowledge, attitude and health
35. Goffman E. Stigma. Notes on the Management of Spoiled Identity. New York: Simon and Shuster. Inc; 1963.

36. Parker R, Aggleton P. HIV and AIDS-related stigma and discrimination: a conceptual framework and implications for action. Soc. Sci. Med. 2003;57(1):13-24.

https://doi.org/10.1016/S0277-9536(02)00304-0 